\title{
Relationship between the lead concentration in hair and occupational exposure
}

\author{
T NICULESCU, ${ }^{1}$ RODICA DUMITRU, ${ }^{1} \mathrm{~V}$ BOTHA, ${ }^{2} \mathrm{R}$ ALEXANDRESCU, ${ }^{1}$ AND \\ N MANOLESCU ${ }^{3}$
}

From the Occupational Health Chair, Medical School and Pneumoconioses Department, ${ }^{1}$ the Institute of Hygiene and Public Health, the Pedology and Agrochemistry Research Institute, ${ }^{2}$ and Research Institute for Vaccines and Biopreparates Pasteur, ${ }^{3}$ Bucharest, Romania

ABSTRACT The lead content of hair in workers occupationally exposed was correlated with the blood lead concentration. Determinations of lead in blood and hair were performed by electrothermal atomic absorption spectrophotometry in two exposed groups and a control group. A significant correlation was observed between the blood lead and hair lead concentrations, and a regression analysis showed an exponential accumulation of the lead content in hair, simultaneously with the increase of the values in blood. The colour of the hair and the age of the subject did not influence the lead accumulation in hair in the occupationally exposed subjects. The assessment of lead in hair is considered a useful screening test in estimating occupational exposure.

During recent years a series of studies have pointed to the use of the content of lead in hair as an index of occupational exposure indicator. ${ }^{1-5}$ Modern analytical techniques now allow the metal content to be measured in sequential segments of hair. ${ }^{26}$

The present study aimed to follow up the examination of lead in a single hair in workers occupationally exposed and to correlate this with the blood lead concentration.

\section{Materials and methods}

Two groups of male workers with differing occupational experience were studied: group 1 comprised 31 subjects exposed to high concentrations of lead in air and group 2, 33 subjects with low exposure. The ages and years of exposure of these two groups are presented in tables 1 and 2.

Blood samples were collected on heparin from each exposed person together with five hairs, including the root. Before the analysis the hair was washed in acetone, ethylic ether, and $1.5 \%$ solution of sodium lauryl sulphate in order to degrease it and remove exogenous lead particles'; segments of exactly $1 \mathrm{~cm}$ in length, measured from the root, were then taken. To verify the cleanliness of the surface, three hairs (before washing, after a single washing,

Received 5 October 1981

Accepted 27 January 1982
Table 1 Age distribution of exposed and control populations

\begin{tabular}{llll}
\hline Group & $\begin{array}{l}\text { Age } \\
\text { (years) }\end{array}$ & $\begin{array}{l}\text { No } \\
\text { exposed }\end{array}$ & $\begin{array}{l}\% \\
\text { exposed }\end{array}$ \\
\hline Controls & $\leqslant 20$ & - & - \\
& $21-30$ & 2 & 20 \\
& $31-40$ & 3 & 30 \\
& $41-50$ & 3 & 30 \\
1 & $>50$ & 2 & 20 \\
& $\leqslant 20$ & 9 & -16.03 \\
& $21-30$ & 8 & $25 \cdot 81$ \\
& $31-40$ & 9 & 29.03 \\
2 & $41-50$ & 5 & 16.13 \\
& $>50$ & 1 & 3.04 \\
& $\leqslant 20$ & 6 & 18.18 \\
& $21-30$ & 7 & $21 \cdot 21$ \\
& $31-40$ & 13 & 39.39 \\
& $41-50$ & 6 & 18.18 \\
\hline
\end{tabular}

Table 2 Distribution of years of lead exposure

\begin{tabular}{llcl}
\hline Group & $\begin{array}{l}\text { Years of } \\
\text { exposure }\end{array}$ & $\begin{array}{l}\text { No } \\
\text { exposed }\end{array}$ & $\begin{array}{l}\% \\
\text { exposed }\end{array}$ \\
\hline 1 & $<5$ & 5 & $16 \cdot 13$ \\
& $5-10$ & 12 & $38 \cdot 72$ \\
& $11-15$ & 6 & $19 \cdot 35$ \\
& $16-20$ & 6 & $19 \cdot 35$ \\
2 & $>20$ & 2 & $6 \cdot 45$ \\
& $<5$ & 8 & $24 \cdot 24$ \\
& $5-10$ & 7 & $21 \cdot 22$ \\
& $11-15$ & 6 & $18 \cdot 18$ \\
& $16-20$ & 8 & $24 \cdot 24$ \\
& $>20$ & 4 & $12 \cdot 12$ \\
\hline
\end{tabular}


Table 3 Distribution of blood lead concentrations

\begin{tabular}{lllrl}
\hline Group & Blood lead & $\begin{array}{l}\text { No } \\
\text { exposed }\end{array}$ & $\begin{array}{l}\% \\
\text { exposed }\end{array}$ \\
\cline { 2 - 4 } & $(\mu g / d l)$ & $(\mu \mathrm{moll})$ & & \\
\hline 1 & $<40$ & $<1 \cdot 93$ & 5 & $16 \cdot 13$ \\
& $40-79$ & $1 \cdot 93-3 \cdot 81$ & 22 & $70 \cdot 97$ \\
& $80-120$ & $3 \cdot 86-5 \cdot 79$ & 3 & $9 \cdot 68$ \\
2 & $>120$ & $>5 \cdot 79$ & 1 & $3 \cdot 22$ \\
2 & $<40$ & $<1 \cdot 93$ & 28 & $84 \cdot 85$ \\
& $40-79$ & $1 \cdot 93-3 \cdot 81$ & 5 & $15 \cdot 15$ \\
& $80-120$ & $3 \cdot 86-5 \cdot 79$ & - & - \\
\hline
\end{tabular}

and after double washing) were examined by scanning electron microscopy.

The lead concentration in the blood and in the segments of hair was determined by an electrothermal atomic absorbtion spectrophotometry method, ${ }^{28}$ using a Pye Unicam SP 9 apparatus equipped with an atomisation furnace with graphite tubes.

Blood and hair lead concentrations were also measured in a control group of 10 men never exposed to lead. They were aged from 21 to 55 (table 1).

\section{Findings and discussion}

The distribution of the blood lead concentrations of exposed groups is presented in table 3 . From these data it is clear that the subjects in group 1 were more heavily exposed than those in group 2 : three sub-

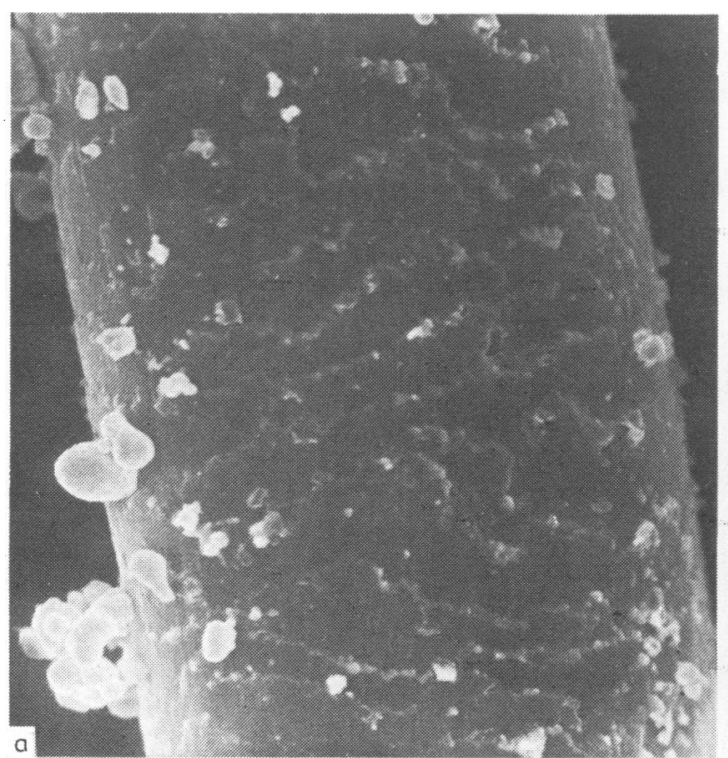

jects in group $1(9.68 \%)$ presented excessive values, while one $(3 \cdot 22 \%)$ presented a value of $137 \mu \mathrm{g} / \mathrm{dl}$ (6.61 $\mu \mathrm{mol} / \mathrm{l})$.

Because of the high sensitivity of the analytical method, it is essential that the surface of the hair is clean. In this study the scanning electron microscopy

Table 4 Mean blood and hair lead concentrations

\begin{tabular}{lllll}
\hline Group & $\begin{array}{l}\text { No of } \\
\text { subjects }\end{array}$ & \multicolumn{2}{l}{ Blood lead } & $\begin{array}{l}\text { Hair lead } \\
(\mathrm{ng} / \mathrm{cm})\end{array}$ \\
\cline { 3 - 4 } & & $(\mu \mathrm{g} / \mathrm{dl})$ & $(\mu \mathrm{mol} / \mathrm{l})$ & \\
\hline Controls & 10 & $24 \cdot 13$ & 1.03 & 0.59 \\
1 & 31 & $58 \cdot 62^{*}$ & $2.82^{*}$ & $5 \cdot 87^{*}$ \\
2 & 33 & 28.23 & 1.36 & $3.50^{*}$ \\
\hline
\end{tabular}

* Statistically significant compared with controls $(\mathrm{p}<0.001)$.

Table 5 Variation of mean lead concentration according to hair colour

\begin{tabular}{|c|c|c|c|c|}
\hline Group & $\begin{array}{l}\text { Hair } \\
\text { colour }\end{array}$ & $\begin{array}{l}\text { No of } \\
\text { subjects }\end{array}$ & $\begin{array}{l}\text { Hair lead } \\
(\mathrm{ng} / \mathrm{cm})\end{array}$ & $\begin{array}{l}\text { Statistical sig- } \\
\text { nificance of the } \\
\text { difference } \\
\text { among colours }\end{array}$ \\
\hline Controls & $\begin{array}{l}\text { Dark } \\
\text { Light } \\
\text { White }\end{array}$ & $\begin{array}{l}5 \\
5 \\
4\end{array}$ & $\begin{array}{l}0.92 \\
0.26 \\
0.41\end{array}$ & $\underline{p<0.025}$ \\
\hline 1 & $\begin{array}{l}\text { Dark } \\
\text { Light } \\
\text { White }\end{array}$ & $\begin{array}{r}11 \\
20 \\
3\end{array}$ & $\begin{array}{l}6 \cdot 23^{*} \\
5 \cdot 59^{*} \\
2 \cdot 36\end{array}$ & $\underline{p}>0.05$ \\
\hline 2 & $\begin{array}{l}\text { Dark } \\
\text { Light } \\
\text { White }\end{array}$ & $\begin{array}{r}12 \\
21 \\
3\end{array}$ & $\begin{array}{l}3 \cdot 56^{*} \\
3 \cdot 50^{*} \\
2 \cdot 56\end{array}$ & $\underline{p}>0.005$ \\
\hline
\end{tabular}

* Statistically significant compared with controls $(p<0.001)$.

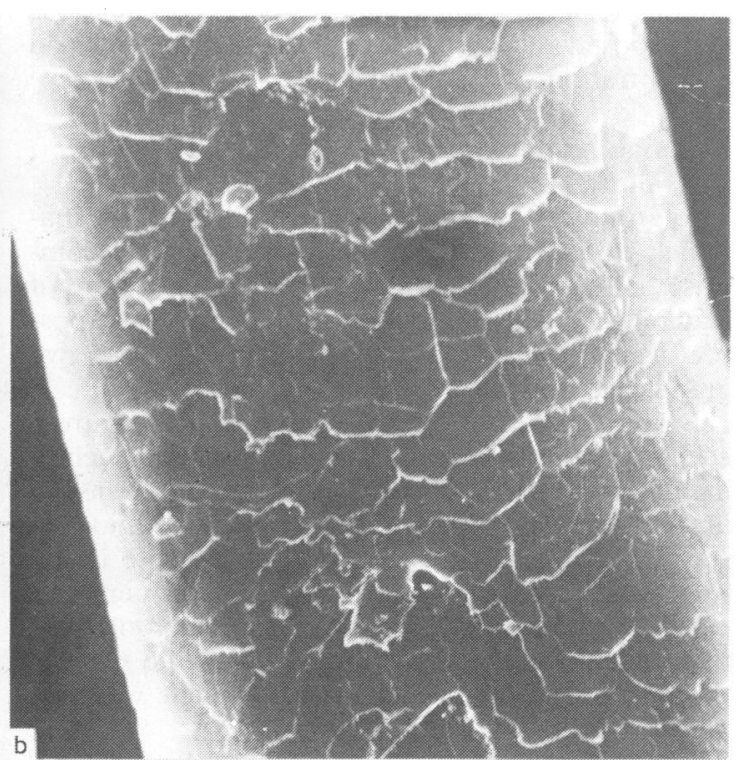

Fig 1 Hair examined by electron scanning microscopy: (a) before washing ( $\times 2000)$; (b) after a double washing with acetone, ethylic ether, and $1.5 \%$ solution sodium lauryl sulphate $(\times 2300)$. 
showed that a double washing with acetone, ethylic ether, and sodium lauryl sulphate ensures a satisfactory purity of the hair surface (fig 1).

Table 4 presents the mean values of lead in blood and hair in the study groups. In group 1 both are significantly greater than in the controls; in group 2 only the mean hair lead is significantly increased. Both values are significantly raised in group $1 \mathrm{com}$ pared with group $2(\mathrm{p}<0.025)$.

Dark hair was found to contain a higher lead concentration than light or white hair (table 5). This is apparently in disagreement with the findings of Schroeder et al, ${ }^{9}$ who found the following variation: dark $>$ blond $>$ black $>$ red. In the present study, however, the difference between the two colours (dark and light) was significant only in the controls. The significance of this fact is that occupational exposure overwhelms any influence which hair colour may have on the lead concentration; this is in agreement with the findings of other authors. ${ }^{21011}$

The lead concentration varied from one single hair to another in the same subject, underlining the necessity of calculating an average value for several single hairs. ${ }^{210}$

The possibility of the existence of a relationship between the lead in hair and age was investigated. Regression analysis showed the absence of a correlation between these parameters in both controls $(r=$ $+0.32, p>0.05$ ) and exposed subjects (group $1 \mathrm{r}=$ $+0.12, p>0.05$ and group $2 r=+0.11, p>0.05)$; age is thus a non-significant factor as regards the accumulation of lead in hair. Other authors ${ }^{2710-12}$ have reported similar findings.

Exogenous lead diffusion within a single hair is said to be lowest in that part of the hair closest to the $\operatorname{root}^{2}$; the segment of hair closest to the root thus reflects exposure better than the subsequent segments. Since the average growth of the hair is about $1 \mathrm{~cm} /$ month, the use of the first and subsequent centimetre lengths of hair for lead analysis will allow the study of the exposure for recent and delimitated periods.

Regression analysis shows a significant correlation in group 1 between the lead concentrations in single hair and blood $(r=+0.72, p<0.001)$; the correlation in group 2 is much less strong $(r=+0.03, p<$ 0.05 ). It can be seen (fig 2) that the exponential accumulation of lead in hair related to the concentration in blood (the regression equation is $y=$ $1.502 \mathrm{e}^{0.018 \mathrm{x}}$, where we considered the lead concentration in blood as the independent variable $x$, and the concentration in hair as dependent variable $y$ ), in accordance with the papers of Grandjean ${ }^{2}$ and Chattopadhyay et al. ${ }^{13}$

From the regression of the logarithm of the lead content in hair against the concentration in blood, a

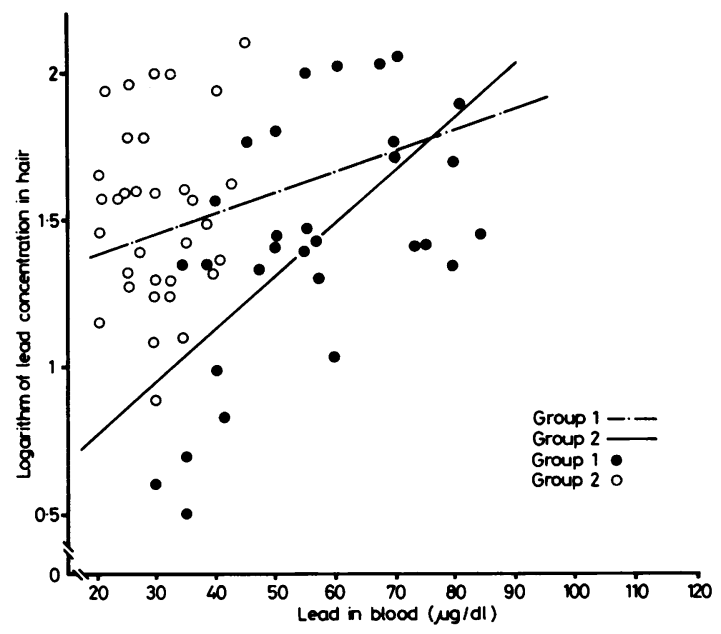

Fig 2 Regression of logarithm of hair lead against blood lead concentrations.

biological limit value of $3 \mathrm{ng} \mathrm{Pb} / \mathrm{cm}$ single hair for a blood value of $40 \mu \mathrm{g} \mathrm{Pb} / \mathrm{dl}(1.93 \mu \mathrm{mol} / \mathrm{l})$ is deduced; for a blood level of $60 \mu \mathrm{g} / \mathrm{dl}(2.89 \mu \mathrm{mol} / \mathrm{l})$ the lead in hair value corresponds to $4 \mathrm{ng} / \mathrm{cm}$. These data are close to the findings of Grandjean, ${ }^{2}$ who found a biological limit of $3 \mathrm{ng} / \mathrm{cm}$ corresponding to a value of $60 \mu \mathrm{g} \mathrm{Pb} / \mathrm{dl}(2.89 \mu \mathrm{mol} / \mathrm{l})$.

\section{References}

' El-Dakhakhny AA, El-Sadik YM. Lead in hair among exposed workers. Am Ind Hyg Assoc J 1972;33:31-4.

${ }^{2}$ Grandjean P. Lead concentration in single hair as a monitor of occupational lead exposure. Int Arch Occup Environ Health 1978;42:69-81.

${ }^{3}$ Hasegawa N, Hirai A, Shibata T, Sugino H, Kashiwagi T, Determination of lead in hair by atomic absorption spectroscopy for simple screening of lead intoxication. Ann Rep Res Inst Environ Med 1971;18:1-5.

4 Kopito L, Byers RK. Schwachman H. Lead in hair of children with chronic lead poisoning. $N$ Eng $J$ Med 1967;276:949-53.

${ }^{5}$ Klevay LM. Hair as a biopsy material. III Assessment of environmental lead exposure. Arch Environ Health 1973;26:169-72.

- Alder JF, Samuel AJ, West TS. The single element determination of trace metals in hair by carbon-furnace atomic absorption spectrometry. Anal Chim Acta 1976;87:313-21.

' Petering HG, Yeager DW, Witherup SO. Trace metal content of hair. II Cadmium and lead of human hair in relation to age and sex. Arch Environ Health 1973;27:327-30.

${ }^{8}$ Alt F, Massmann H. Bestimmung von blei in blut mittels atomabsorptionsspektrometrie. Spectrochimica Acta 1978; 33B: $337-42$.

- Schroeder HA, Nason AP. Trace metal in human hair. $J$ Invest 
Dermatol 1969;53:71-8.

${ }^{10}$ Creason JP, Hinners TA, Bumgarner JE, Pinkerton C. Trace elements in hair, as related to exposure in metropolitan New York. Clin Chem 1975;21:603-12.

" Reeves RD, Jolley KW, Buckley PD. Lead in human hair: relation to age, sex and environmental factors. Bull Environ Con- tam Toxicol 1975;14:579-87.

12 Eads EA, Lambdin CE. A survey of trace metals in human hair. Environ Res 1973;6:247-52.

${ }^{13}$ Chattopadhyay A, Roberts TM, Jervis RE. Scalp hair as a monitor of community exposure to lead. Arch Environ Health 1977;32:226-36. 